\title{
Relationship between Socioeconomic Demographic Characteristics with Antibiotic Self-Medication in Community Dwelling Adults
}

\author{
Michael Aditya, ${ }^{1}$ Istriati, $^{2}$ Aih Cahyani ${ }^{3}$ \\ ${ }^{1}$ Faculty of Medicine Universitas Padjadjaran, ${ }^{2}$ Department of Pharmacology and Therapy Faculty \\ of Medicine, Universitas Padjadjaran, ${ }^{3}$ Department of Neurology Faculty of Medicine Universitas \\ Padjadjaran/Dr. Hasan Sadikin General Hospital Bandung
}

\begin{abstract}
Background: Infectious diseases escalation in developing countries especially in Indonesia lead to increasing use of antibiotics in the community. Self-medication with antibiotics may increase the risk of resistant bacteria and irrational use of antibiotics. This study was conducted to determine the relationship between socioeconomic -demographic characteristics with antibiotic self-medication.

Methods: An analytical cross sectional study was conducted on people from Sayang Village in West Java Indonesia aged over 18 years and had experience in using antibiotics. A total of 146 respondents were selected as the sample of this study. A validated questionnaire was used to collect data. Data were analysed by using descriptive statistics and Chi-Square test to analyze the relationship between socioeconomic demographic characteristics with antibiotic self-medication.

Results: Out of 146 questionnaires that were completed, 111 were female and 35 male respondents, 75 respondents had experience in using antibiotics without prescription. The survey showed significant relation between antibiotics use with monthly income $(p=0,031)$ and source of income $(p=0,009)$.

Conclusions: The study confirms that there is relation between monthly income and source of income with antibiotic self-medication. [AMJ.2017;4(1):73-7]
\end{abstract}

Keywords: Antibiotics, self-medication, socioeconomic -demographic characteristics

\section{Introduction}

The escalation of infectious diseases is still a major health problem in developing countries especially in Indonesia. It reflected the fact based on the Indonesian Health Profile in 2005 that the most common health problem of Indonesian people was infectious disease. ${ }^{1}$ Characteristics of the diseases that could be transmitted to the other individual increased the demand of drugs to treat these infectious diseases. Antibiotics was already well-known and commonly consumed for treating bacterial infections but the usage is highly restricted and must be taken under prescription since irrational use of antibiotics might build a resistance pattern from bacteria to antibiotics. One of the examples of irrational use of antibiotics that could lead to resistance of bacteria was the development of multidrug-resistant tuberculosis (MDR-TB) and
Indonesia is classified as a high burden country due to high incidence of MDR-TB $1.9 \%$ from new cases and $12 \%$ from retreatment cases). ${ }^{2}$

Many factors could affect the behaviour and intention of people in using antibiotics. One of the factors that is related with that behaviour is the socioeconomic-demographic characteristics. This factor could affect the people's decisions to buy and use antibiotics by himself/herself without prescription and build an assumption that many people will do self-medication ${ }^{3}$ into diseases that commonly occurred and treated like infectious diseases. This behaviour may increase the demand of antibiotics in the community.

Studies conducted in many countries like in the United States ${ }^{4}$, Indonesia,6, Greek ${ }^{7}$, India $^{8-10}$, Nigeria ${ }^{11}$, Jordania ${ }^{12}$, $\operatorname{Iran}^{13}$ and in other countries showed a surprising fact that the use of antibiotics without prescription in those countries was fairly high. A review of literature revealed that similar studies have

Correspondence: Michael Aditya L, Faculty of Medicine, Universitas Padjadjaran, Jalan Raya Bandung-Sumedang Km.21, Jatinangor, Sumedang, Indonesia, Phone: +62 8569175300 Email: michaeladityalesmana@gmail.com 
already been conducted in many countries including Indonesia, specifically in Medan but the differences in ethnicity and geographical condition differentiates the other studies with this study despite of similarity of the socioeconomic-demographic characteristics such as sex, age, level of education and monthly income. The purpose of this study was to determine the relationship between socioeconomic-demographic characteristics with antibiotic self-medication in community dwelling adults.

\section{Methods}

An analytical cross sectional study was conducted within people in Sayang Village aged above 18 years and had experience in using antibiotics during the past year. This village is located in Sumedang, West Java Indonesia and is one of the selected places where many studies were conducted by medical students from the Faculty of Medicine, Universitas Padjadjaran Bandung. Consecutive sampling technique was used to select samples and a total of 146 respondents who had experience in using antibiotics during the past year were selected. This study has also already received the ethical approval from the Health Research Ethics Committee (No.152/UN6.C2.1.2) KEPK/201). A verbal consent was taken after the surveyor explained the aim of the study and if the people agreed to be a respondent they also signed an informed consent. A validated questionnaire from a previous research in Medan $^{5}$ was used to collect antibiotic selfmedication and socioeconomic-demographic data, such as gender, age, level of education, monthly income and source of income. Respondents were also asked whether they had used antibiotic without prescription during the past year or not.

Table 1 Characteristics of Subjects based on Gender, Age Category, Level of Education, Monthly Income, Source of Income and Antibiotic Self- Medication

\begin{tabular}{lcc}
\hline \multicolumn{1}{c}{ Variable } & $\mathbf{n}$ & $\mathbf{\%}$ \\
\hline Gender & & \\
$\quad$ Female & 111 & 76.0 \\
$\quad$ Male & 35 & 24.0 \\
Age Category & & \\
$\quad<30$ years & 31 & 21.2 \\
$\quad 30-39$ years & 49 & 33.6 \\
$\quad$ 40-59 years & 36 & 24.7 \\
$\quad>50$ years & 30 & 20.5 \\
Level of Education & & \\
$\quad$ Primary Education & 24 & 16.5 \\
$\quad$ Secondary Education & 104 & 71.2 \\
$\quad$ University Graduate & 18 & 12.3 \\
Monthly Income (Rp.) & & \\
$\quad \leq 1.381 .700$ & 75 & 51.4 \\
$\quad$ 1.381.700 & 71 & 48.6 \\
Source of Income & & \\
$\quad$ Non Fixed Income & 59 & 40.4 \\
Fixed Income & 87 & 59.6 \\
Antibiotic Self-Medication & & \\
$\quad$ Without Prescription & 75 & 51.4 \\
With Prescription & 71 & 48.6 \\
\hline
\end{tabular}


Table 2 Bivariate Analysis of Socioeconomic-demographic Characteristics with Antibiotic Self-Medication

\begin{tabular}{|c|c|c|c|}
\hline \multirow{2}{*}{ Variables } & \multicolumn{2}{|c|}{ Antibiotic Self-Medication } & \multirow{2}{*}{ p value } \\
\hline & With Prescription & Without Prescription & \\
\hline \multicolumn{4}{|l|}{ Age Category } \\
\hline$<30$ years & 18 & 13 & 0.810 \\
\hline 30-39 years & 24 & 25 & \\
\hline $40-59$ years & 17 & 19 & \\
\hline$>50$ years & 16 & 14 & \\
\hline \multicolumn{4}{|l|}{ Level of Education } \\
\hline Primary Education & 11 & 13 & 0.639 \\
\hline Secondary Education & 56 & 48 & \\
\hline University Graduate & 8 & 10 & \\
\hline \multicolumn{4}{|l|}{ Monthly Income (Rp.) } \\
\hline$\leq 1.381 .700$ & 32 & 43 & 0.031 \\
\hline$>1.381 .700$ & 43 & 28 & \\
\hline \multicolumn{4}{|l|}{ Source of Income } \\
\hline Non Fixed Income & 38 & 21 & 0.009 \\
\hline Fixed Income & 37 & 50 & \\
\hline
\end{tabular}

Descriptive statistic and bivariate analysis was performed sequentially to determine relationship from each of the socioeconomicdemographic variables with antibiotic selfmedication. A descriptive analysis was performed to count every characteristic that would be tested and described every independent and dependent variables using tables of frequency distribution and percentage of each variable. Finally, the bivariate analysis was conducted in this study to find any relation between every variable with antibiotic selfmedication by using the Chi-Square test. The result was considered statistically significant if the variable had a $p$-value $<0.05$.

\section{Results}

There were 146 respondents involved in this study, with 75 respondents (51.4\%) were self-medicating and using antibiotics without prescription. Analysis from the questionnaires showed that the highest gender of respondents were female with 111(76.0\%) respondents who joined this study with median of age 38 years ranging from the youngest respondent was 18 years old and the oldest respondent was 72 years old. The educational level of respondents was mostly distributed in the secondary education level. The mean of monthly income from the respondents was Rp.1.920.890,00 and mostly came from fixed income (Table 1).

Antibiotic self-medication was significantly affected by monthly income $(\mathrm{p}=0.031)$ and source of income $(p=0.011)$ but not by age and level of education (Table 2).

\section{Discussions}

From 146 respondents who were involved in this study 75 respondents (51.4\%) were self-medicating and using antibiotics without prescription, 124 respondents $(84.9 \%)$ had already known that the use of antibiotics must be with a prescription from the physician. The reasons for using antibiotics without prescription were mostly because of economic reason and the previous experience with antibiotics. The previous experience with antibiotics was the main source of information that respondents used when deciding to use that medication again for the second time. Most of the respondents $(n=67)$ used antibiotics for a short period of time. They decided to stop the medication with antibiotics after the 
symptoms subsided. This could be due to lack of education from the prescribing physician and/or dispensing pharmacist as the patients should be counselled about the treatment regiment.

The most respondents in this study were in the age category 30-39 years with 46 respondents $(35.4 \%)$ in each category. The Chi-square test between the variable of age category with antibiotic self-medication showed p-value in the amount of 0.810 . The result showed that there was not any significant relation between age category and antibiotic self-medication. This findings was different with previous studies performed in Sudan ${ }^{14}$ and United Arab Emirates ${ }^{15}$ that showed a significant relation between age category and antibiotic self-medication. However another study in Yogyakarta also showed no relationship between age and antibiotic self-medication. ${ }^{6}$ Further studies and investigation must be performed due to possibilities of people especially who lies in the active age group to have self-medication and tended to have more complaints, for instance, stress of family problems and daily market schedule. On the other hand, the lowest used rate among the younger age group might be caused of some of them may still be in school or learning a trade, usually have less complaint, and low purchasing power. ${ }^{11}$

The educational level of the population in Sayang Village was already good enough since 104 respondents $(71.2 \%)$ graduated from the secondary education grade and not any illiterate individual joined this study. The Chi-square test between level of education variable and antibiotic self-medication failed to show any significant relation $(\mathrm{p}=0.639)$. The results are similar with studies in Medan ${ }^{5}$ and Yogyakarta ${ }^{6}$ that also could not find any significant relation between level of education with antibiotic self-medication. However, this findings was different with the previous studies in Nigeria ${ }^{11}$, Sudan $^{14}$ and United Arab Emirates ${ }^{15}$ which showed a significant relation between level of education with antibiotic selfmedication. This could be due to differences of the educational system in those countries with the educational system in Indonesia. Although educational level was not showing any relationship with antibiotic self-medication in this study, a further investigation must be conducted due to relation of educational level that could affect people's insight when accepting a medical information, where people with a higher level of education tend to have a higher knowledge in understanding a medical information. ${ }^{16}$ People with a higher level of education also feel that a hospital or pharmacy have well-trained personnel rather than a patent medicine dealer in drug dispensing. ${ }^{11}$

Economic considerations were important in this study. From the results of this study, out of 146 respondents, there were 75 respondents (51.5\%) who had a monthly income that equalled to $\mathrm{Rp} 1.381 .700,00$ or less and only 87 respondents (59.6\%) who had a fixed income. This finding raised a notion that there were a lot of people in Sayang Village that still had a low monthly income. The result from the chi-square test between monthly income variable and antibiotic self-medication showed that there was a significant relation between monthly income $(p=0.031)$ and source of income $(p=0.009)$. This finding was different with the previous studies conducted in Medan ${ }^{5}$ and Yogyakarta ${ }^{6}$ that could not find any significant relation between monthly income with antibiotic selfmedication. This result can differ due to the differences of culture and ethnicity of people in Medan, Yogyakarta and in Jatinangor which could affect the consumption behaviour of the people. However, this study showed a similar relation with a study in Jordania that also showed a significant relation between these two variables. ${ }^{12}$ The similar result between the study in Jordania and Jatinangor had an unknown cause. Furthermore, this study had limitations. There was a possibility that the collected information was biased. In addition, because the respondents were exposed by the similar economic and environmental conditions, their complaints and responses tended to be similar. The future studies would ideally follow the respondents to gain a deeper insight into the antibiotic self-medication.

This study concluded that there is a significant relation between economic characteristics with antibiotic self-medication.

\section{References}

1. Departemen Kesehatan RI. Profil kesehatan Indonesia. Jakarta: Depkes RI; 2005.

2. World Health Organization. Global Tuberculosis Report 2013. Geneva: WHO Press; 2013.

3. World Health Organization. WHO Global Strategy for Containment of AMR and Implementing it at Local and WHO Global Strategy for Containment of AMR. Moshi: EPN; 2008.

4. Larson E, Grullon-Figueroa L. Availability of Antibiotics without Prescription in New 
York City. J Urban Health.2004;81(3):498504.

5. Hendriani M. Hubungan antara karakteristik masyarakat dengan penggunaan antibiotik yang diperoleh secara bebas di Kota Medan [thesis]. Medan: University of Sumatera Utara; 2009.

6. Widayati A, Suryawati S, de Crespigny C, Hiller JE. Self medication with antibiotics in Yogyakarta City Indonesia: a cross sectional population-based survey. BMC Res Notes.2011;4(1):491.

7. Mitsi G, Jelastopulu E, Basiaris H, Skoutelis A, Gogos C. Patterns of antibiotic use among adults and parents in the Community: a Questionnaire-based survey in a Greek Urban Population. Int J Antimicrob Agents.2005;25(5):439-43.

8. Wattal C. Development of antibiotic resistance and its audit in our country: how to develop an antibiotic policy. Indian J Med Microbiol.2012;30:381-3.

9. Jain P, Sachan A, Singla RK, Agrawal P. Statistical study on self medication pattern in Haryana , India. Indo Global Journal of Pharmaceutical Sciences.2012;2(1):21-35.

10. Loharkar N, Keche Y, Yegnanarayan R, Dharma M, Bhosale A. Self-medication use in urban population of Pune, Maharashtra, India. Sch J App Med Sci.2013;1(6):732-8.
11. Afolabi A. Factors influencing the pattern of self-medication in an adult Nigerian population. Ann Afr Med.2008;7(3):120-7.

12. Al-Azzam SI, Al-Husein BA, Alzoubi F, Masadeh MM, Al-Horani MA. Self medication with antibiotics in Jordanian population. Int J Occup Medi Environ Health.2007;20(4):373-80.

13. Heidarifar R, Koohbor M, Mansourabad KM, Mikaili P, Sarahroodi S. Self-medication with antibiotics among Iranian Population in Qom State. Journal of Scientific and Innovative Research.2013;2(4):785-9.

14. Awad A EI, Matowe L, Thalib L. Selfmedication with antibiotics and antimalarials in the community of Khartoum State, Sudan. J Pharm Pharm Sci.2005;8(2):326-31.

15. Abasaeed A, Vlcek J, Abuelkhair M, Kubena A. Self-medication with antibiotics by the community of Abu Dhabi Emirate, United Arab Emirates. J Infect Dev Ctries.2009;3(7):491-7.

16. Sariningrum E, Irdawati. Hubungan Tingkat Pendidikan, Sikap dan Pengetahuan Orang Tua tentang Kebersihan Gigi dan Mulut pada Anak Balita 3-5 Tahun dengan Tingkat Kejadian Karies di PAUD Jatipurno [thesis]. Surakarta: Muhammadiyah University of Surakarta 2009. 